\title{
DEBATINDLAEG
}

\section{Linedans: Når frivillige og medarbejdere tager en svingom på velfærdsstatens travle gulv}

\author{
Mona Striib
}

Mange af os vil gerne give en hånd med. Nogle står i en genbrugsbutik for Red Barnet, andre er med til at afvikle sportsstævnet for lilleputholdet, mens andre cykler en tur med en beboer fra plejecenteret. Den frivillige indsats er en naturlig del af vores samfund til glæde for os alle.

Det er prisværdigt, når empatiske og energiske mennesker får øje på et behov for støtte eller hjælp, og forsøger at gøre noget ved det. Og med de besparelser og nedskæringer vi har set i den offentlige sektor de seneste ti år, er det desværre ikke svært at få øje på, hvor og hvem man kan gøre en meningsfuld forskel for.

Flere og flere frivillige fra civilsamfundet er med til at løse vigtige velfærdsopgaver. På den ene side er det godt, fordi de gør en forskel for deres medmennesker. På den anden side er det et problem. De frivillige overtager nemlig flere og flere af de opgaver, der førhen blev varetaget af uddannede medarbejdere. Og det kan give mærkbare problemer for den faglige kvalitet i velfærden, når frivillige indtager arbejdspladsen uden dialog og aftaler. Det er helt uigennemtænkt, hvilke konsekvenser det $\mathrm{i}$ fremtiden får for vores universelle velfærd.

\section{Færre ansatte, flere frivillige}

Forholdet mellem antallet af offentligt ansatte og antallet af borgere er det laveste i over 30 år. Dansk Statistik oplyser, at antallet af kommunalt ansatte de seneste knap 10 år er faldet med 33.000. Mere end hvert tredje FOA-medlem oplever, at frivillige i stigende omfang overtager opgaver. Hvis man er lokal politiker og gerne vil tilbyde en værdig hjælp til syge og svækkede borgere i kommunen, kan det ligge lige til højrebenet at gøre brug af frivillige. Hvorfor ikke?

En femtedel af FOAs medlemmer er bekymrede for, at brugen af frivillige fører til arbejdsløshed for deres faggruppe. Det er en reel bekymring for den enkelte, men for den lokale politiker, der ser en mulighed for gratis hænder, der meget gerne vil hjælpe til, er det måske ikke et argument, der taler imod brugen af frivillige. I FOA har vi også set mange eksempler på kommuner, der $\mathrm{i}$ stigende omfang benytter frivillig arbejdskraft og dermed sparer medarbejdere væk. Nogle gange sker det som en glidende overgang, andre gange lukker man simpelthen et kommunalt dagcenter, en genbrugsstation eller bibliotek for at lade det genopstå med frivillig arbejdskraft. 


\section{Hvad er problemet?}

Er udviklingen et problem for andre end de medarbejdere, der måske oplever, at deres jobs bliver overtaget af frivillige? Er der andre argumenter mod øget brug af frivillige? For at nuancere problematikken kan man i første omgang nævne, at frivilliges indsats ikke er tilstrækkelig, hvis vi vil genoprette vores velfærdssamfund efter årtier med nedskæringer. Hvis vi vil genoprette det velfærdssamfund, hvor alle, også syge og svage, børn og ældre, kan føre et værdigt liv, og hvis vi vil genoprette lige adgang til uddannelse, kultur og så videre, så kræver det flere medarbejdere med fagligheden i orden. Det er den garant for retssikkerhed, ligebehandling og driftssikkerhed, som er en af velfærdsstatens hovedhjørnesten.

Hvis tendensen til at bruge frivillige til vigtige velfærdsopgaver fortsætter, vil det netop underminere retssikkerheden, ligebehandlingen og driftssikkerheden. For behovet for, at borgerne leverer en frivillig indsats, vil altid afhænge af demografien og den sociale profil i det givne område. Der hvor behovet for hjælp er størst, er ikke nødvendigvis også der, hvor flest har mulighed for og ønsker at bidrage med en frivillig indsats. For eksempel fortæller næsten 80 procent af FOA-medlemmerne på plejecentrene, at der er frivillige på deres arbejdsplads. I hjemmeplejen er det kun 16 procent og på handicapområdet 23 procent. Og hvert tredje FOA-medlem er bekymret for, om brugen af frivillige på plejecentre, i hjemmeplejen og på handicapområdet har negative konsekvenser for den hjælp og pleje som deres medborgere har krav på.

Uden hverken personale eller frivillige vil opgaven falde tilbage på familier og venner. Og som pårørende vil "arbejdsmængden" være afhængig af, hvilket kort ens familie og venner har trukket i livets lotteri. Har man for eksempel to friske, rørige forældre eller er de kronisk syge? Det sidste vil påvirke muligheden for at skabe et liv med balance mellem arbejde og fritid, mellem at have ansvaret for andres ve og vel og at have tid til at tage vare på sig selv.

\section{Det frivilliges særlige værdi}

Der er brug for den frivillige indsats, også på det sociale område. Frivillige har en anden forudsætning for at indgå $\mathrm{i}$ et ligeværdigt forhold, end personalet har. Den frivillige kommer fordi, hun har lyst til at bruge sin fritid sammen med Jørgen på 89, som sidder alene det meste af dagen, eller sammen med Marie, som er hjemløs og lider af en psykisk sygdom. Det er livsbekræftende. Men hvornår tipper balancen mellem antallet af frivillige og antallet af fagligt stærke medarbejdere?

I FOA mener vi, at kommunerne skal have en knivskarp forståelse for den særlige værdi, som en frivillig indsats har og ikke forveksle det med det, en ansat er forpligtet til og rent fagligt er i stand til: At man gennem sin arbejdspligt, lydighedspligt, loyalitetsforpligtelse, tavshedspligt og faglighed er garant for, at også "den sure ensomme gamle mand" får hjælp. Ellers underminerer det både vores velfærdsmodel OG det helt særlige, som civilsamfundet kan: Den umiddelbare, utvungne og frivilligt givet hjælp til et andet menneske. Der er en stor risiko for, at netop det umiddelbare og utvungne fortrænges, når kommunerne sætter frivilligheden i system for at dække et kommunalpolitisk behov, for eksempel ved at kommunen selv begynder at rekruttere frivillige.

At respektere det frivilliges særlige værdi ved $i k k e$ at forveksle det med det, en ansat kan, er vel klar tale og alligevel et princip, som kræver lokal oversættelse. Der vil være forskel på, hvordan introduktionen af nye frivillige, opgavefordelingen og samarbejdet mellem frivillige og ansatte skal være alt afhængig af hvilken arbejdsplads, vi er på og 
hvilke opgaver, der skal løses. Der er forskel på at være frivillig på et hospital og i en børnehave. På et demensafsnit og i køkkenet.

\section{Et godt samarbejde hviler på fælles aftaler}

FOA mener, at det er helt afgørende, at ledelsen og tillidsrepræsentanterne på de offentlige arbejdspladser sætter sig rundt om det samme bord og aftaler, hvordan samarbejdet med frivillige skal være lige præcis hos os. Og aftalerne skal være så konkrete, at den enkelte medarbejder ikke skal bruge sin knappe tid på usynligt arbejde med at lede og fordele arbejdet blandt de frivillige og løse konflikter om, hvordan det faglige arbejde skal løses. På Horsens Hospital har ledere og medarbejdere for eksempel lavet en klar retningslinje, som beskriver hvilke opgaver, frivillige kan løse, hvordan der rekrutteres frivillige, hvordan de introduceres til arbejdsstedet og så videre. Der står også tydeligt, at de frivillige ikke udfører personalets opgaver og ikke blander sig i personalets beslutninger. Uden så klare aftaler kan der opstå konflikter, og det kan tære på personalets overskud og arbejdsglæde, som i dette eksempel fra et FOA-medlem på social- og sundhedsområdet:

Nogle gange oplever jeg, at de [frivillige] korrekser os fagloert personale i hvad der er bedst for beboerne. Jeg har det MEGET svaert i disse situationer, for det er jo os fastansatte, fagloert uddannet personale med kurser inden for de- mens, der kender beboerne bedst og med vores faglighed ved, hvorfor det er bedst, at vi gør som vi gør i den givne situation. (...) Vi (det fastansatte fagloerte personale) føler os ikke hørt og bakket nok op af vores ledelse. Vi føler, at det er en kamp mellem dem og os. Citat fra FOAs medlemsundersøgelse

"Frivilligt arbejde", 2018

Fælles retningslinjer er med til at sikre et godt arbejdsmiljø, både for de ansatte og de frivillige. Vi ved blandt andet, at når FOA-medlemmers nærmeste leder drøfter brugen af frivillige med FOAs medlemmer, oplever de i mindre grad, at de frivillige overtager de opgaver, der giver arbejdsglæde. På arbejdspladser hvor lederen drøfter frivillighed med de ansatte oplever 12 procent at gode arbejdsopgaver forsvinder. Når de ikke drøfter det, oplever 20 procent det samme.

Men noget tyder på, at ledere og medarbejdere kan blive meget bedre til sammen at få taget hul på drøftelsen og lavet aftalerne. Hver tredje FOA-tillidsrepræsentant eller arbejdsmiljørepræsentant svarer i en undersøgelse fra 2018, at de ikke har behandlet emnet i deres samarbejdsorgan (MED-udvalg). Og kun lidt over halvdelen har retningslinjer for brugen af frivillige på deres arbejdsplads. Det bør både vi i fagforeningerne og ledelsen i kommunerne og regionerne gøre noget ved. For et godt samarbejde mellem ansatte og frivillige i den offentlige sektor er en forudsætning for, at den universelle velfærd ikke bare glider os af hænde i en sky af frivillighed.

Mona Striib, forbundsformand i FOA

e-mail: joga@foa.sk 